\title{
MORPHOLOGICAL CHARACTERIZATION OF THE ARTIFICIAL HYBRID BETWEEN STANHOPEA COSTARICENSIS AND STANHOPEA CIRRHATA (ORCHIDACEAE)
}

\author{
WiLLIAM RAMÍREZ ${ }^{1}$ \& GUSTAVO ROJAS ${ }^{2,3}$ \\ 'Emeritus Professor, Facultad de Ciencias Agroalimentarias, Universidad de Costa Rica \\ ${ }^{2}$ Jardín Botánico Lankester, Universidad de Costa Rica \\ ${ }^{3}$ Escuela de Biología, Universidad de Costa Rica
}

\begin{abstract}
We report the production of a hybrid between Stanhopea costaricensis and S. cirrhata by artificial pollination. The hybrid plant and flowers are described. The flowers were normal and inherited morphological characteristics of both parent species. It is postulated that species of plants, like in the genus Stanhopea, that have very specific pollinators, have not evolved genetic mechanisms of isolation.

RESUMEN: Se informa sobre la producción de plantas híbridas entre Stanhopea costaricensis y S. cirrhata, por medio de polinización manual. Se describe el híbrido obtenido. Las flores del híbrido eran normales y heredaron características de ambas especies madre. Se postula que especies de plantas que dependen de polinizadores muy específicos, como en el género Stanhopea, no han evolucionado mecanismos genéticos de aislamiento.
\end{abstract}

Key words / Palabras Clave: Orchidaceae, Stanhopea costaricensis, Stanhopea cirrhata, hybridization, artificial pollination.

Stanhopea costaricensis Rchb. f. has large and conspicuous flowers with purple ring spots, born on pendulous, several-flowered inflorescences. Its geographical distribution spans from El Salvador to Panama (Jenny 1993). This species is related to $S$. cirrhata Lindl., which ranges from Nicaragua to Panama (Jenny 1993). Stanhopea cirrhata has geminate, lateral inflorescences. Both species belong to morphologically separated Stanhopea groups which differ especially in the morphology and size of the labellum. The lip of $S$. costaricensis has long horns, while $S$. cirrhata lacks them. Both species are geographically isolated by mountain ranges in Costa Rica and Panama; S. costaricensis is found in the Atlantic watreshed, at mid and low altitudes, while $S$. cirrhata is found in the lowlands and altitude range of the Pacific side (Jenny 1993). Both species are pollinated by euglossine male bees (Dressler 1967).

Flowers of $S$. costaricensis were manually pollinated with pollinia of $S$. cirrhata, in September 2000 . The parent plants were cultivated in the greenhouse of one of the authors (WR) in Santo Domingo de Heredia $\left(9^{\circ} 58^{\prime} 46.23^{\prime}{ }^{\prime} \mathrm{N}, 84^{\circ} 41.52\right.$ '
14' 'W). Capsules matured at the start of year 2001. Seeds from one capsule were cultivated in vitro in the laboratory of Ing. Yolanda Chaverri Jiménez. Several seedlings were planted in individual pots containing arborescent fern roots as a substratum, in the greenhouse mentioned before, and two plants bloomed in October 2005. The floral characteristics of the hybrid flower, as well as those of the parent species, are illustrated (Fig. 1-3). The morphology of a hybrid plant and the flower are described herein:

\section{Stanhopea costaricensis $\times$ cirrhata}

Plant epiphytic with creeping rhizome and clustered growths. Pseudobulbs oval, always unifoliate. Leaves coarse and leathery, petiolate, lanceolate, plicate and acute, 30-35 cm long, 10-15 cm wide, petiole $10-15 \mathrm{~cm}$ long, round in cross section with one side notched. Inflorescence directed downwards from the base of the bulb, up to $10 \mathrm{~cm}$ long and two-flowered; entire inflorescense covered by large, spread out broadly triangular and acute bracts. Flowers $5-7 \mathrm{~cm}$ large, sepals and petals beige with dispersed red spots, standing closer towards the 


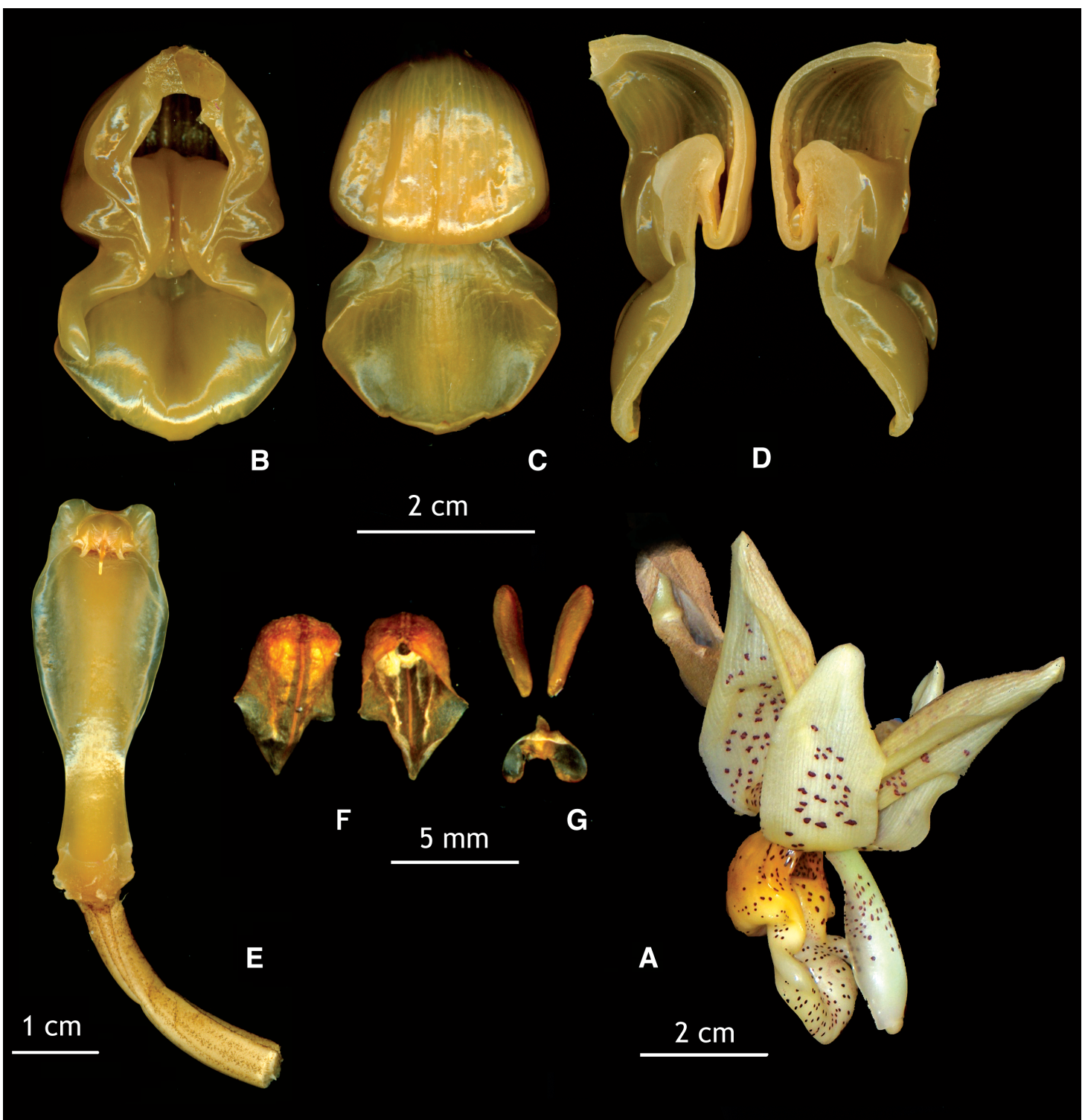

FIGURE 1. Stanhopea costaricensis x Stanhopea cirrhata: A - Flower. B -Lip (front view). C - Lip (dorsal vew). D - Lip dissected. E - Column. F - Anther cap, two views. G - Pollinarium. Scanned by Gustavo Rojas.

base; lip gold yellow with fine red dots and a small eyespots; column white with fine red spots. Dorsal sepal oval, concave, acute, 5-6 cm long, $4 \mathrm{~cm}$ wide. Lateral sepals asymmetric, ovate, acute with same sizes than dorsal one. Petals narrowly lanceolate, acute, undulate, $5 \mathrm{~cm}$ long, $2 \mathrm{~cm}$ wide. Lip $4.5 \mathrm{~cm}$ long, $2.5 \mathrm{~cm}$ wide, saccate, flat at the bottom, without a knee, opening ovate, bridge broad and short, towards front and back lightly triangularly widened; hypochile ovate without edge at the transition to mesochil; epichile broadly ovate fused to the front part of rudimentary horns of $1.5 \mathrm{~cm}$. Column slender at the base, lightly curved and winged, with small horns protruding at the apex, 4.5-4.8 cm long, $1.3 \mathrm{~cm}$ wide. Pollinarium $6 \mathrm{~mm}$ long; pollinia 2, elongate on narrow stipes, and a cordate viscidium.

\section{Discussion}

Stanhopea flowers are exclusively pollinated by euglossine male bees (Dressler 1968), which are 


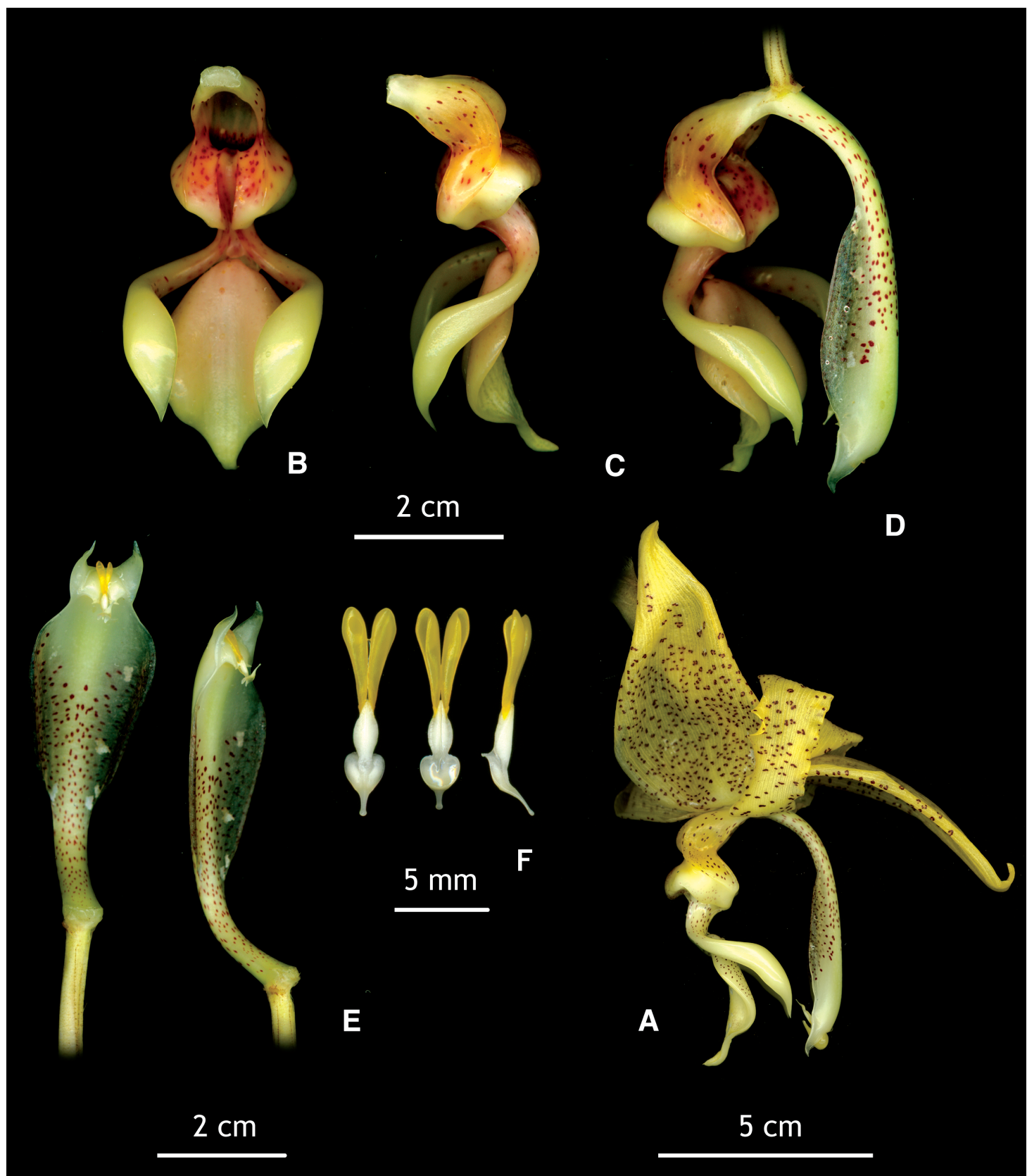

Figure 2. Stanhopea costaricensis. A - Flower. B - Lip (front view). C - Lip (lateral view). D - Lip and column. E - Column. F - Pollinarium, three views. Scanned by Gustavo Rojas.

attracted by floral odors. These bees store the orchid odors in the inflated hind tibia and are supposed to be use as attractants or in the courtship with the female partners (Dodson et al. 1969). The symbiotic relationship Stanhopea - euglossine bees are quite specific (Dressler 1968) and, although some species are visited by several bee species, they are usually pollinated by one or few species.

Natural hybridization of $S$. costaricensis by $S$. cirrhata is not easy to occur because they do not share the same pollinators. Stanhopea costaricensis is visited by medium size to large euglossine males 


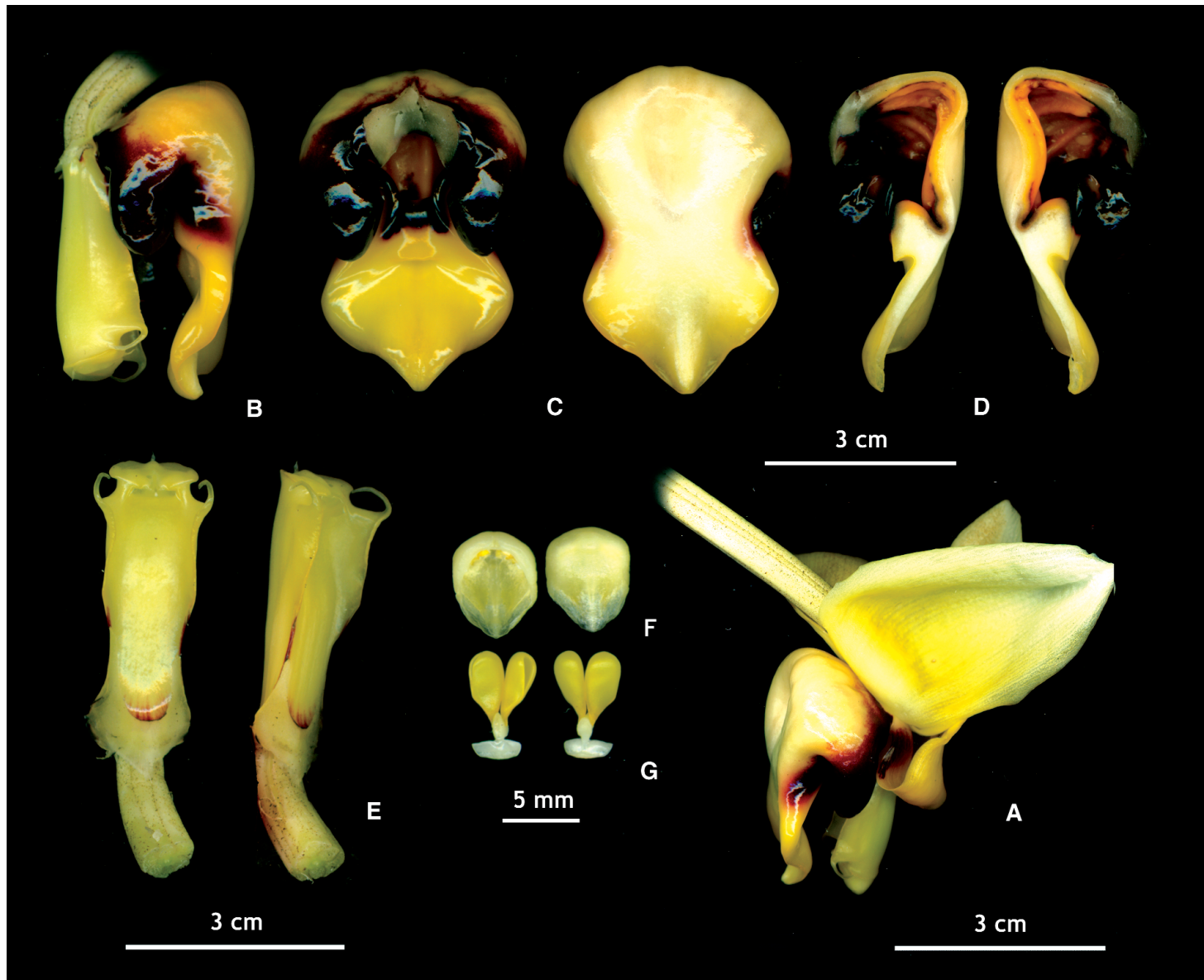

Figure 3. Stanhopea cirrhata. A - Flower. B - Lip and column. C - Lip, two views. D - Lip dissected. E - Column. F Anther cap, two views. G - Pollinarium, two views. Scanned by Gustavo Rojas.

of the genera Eufresia and Eulaema, while S. cirrhata is visited by small Euglossa males. The difference in the pollination syndrome between orchid species may be due to the production of different attractants and a different floral morphology and colors, specially the conformation of the column and labellum (Fig. 2-3) which is probably fundamental in the pollination mechanism.

The flowers of the Stanhopea hybrid obtained had the general morphology of the genus and did not present visual abnormalities. They had characteristics found in both the parent species, however the $S$. costaricensis phenotype predominated, e.g. the hybrid has the labellum divided into three parts and a distinct epichile, a long, curved and slender column, with the wings restricted to the two apical thirds (Fig. 1E), while in $S$. cirrhata the labellum is divided into two parts, the epichile is rudimentary, and the short, erect, massive column is winged from the base. The most striking characters of the hybrid flower are the general white cream color with solid purple spots and the presence of rudimentary horns, which are long in $S$. costaricensis and absent in S. cirrhata. There are few published records about natural hybrids in the genus Stanhopea. Natural hybrids are reported by Dressler (1993) between $S$. ecornuta Lem. and species with large horns, e.g. S. ecornuta x S. costaricensis (see also Jenny 1993). According to Dressler (1968) the paucity of interspecific hybrids in Stanhopea suggest that mechanical or other barriers are partially effective in this case.

It is postulated that plant species that possess very specific pollinators have not evolved genetic isolating mechanisms, and this could explain the 
easiness why artificial commercial hybrids are obtained.

\section{Literature Cited}

Dressler, R.L. 1968. Pollination by euglossine bees. Evolution 22(1):202-210.
Dressler, R.L. 1993. Phylogeny and classification of the orchid family. 314 p. Portland: Dioscorides Press.

Dodson, C.H., R.L. Dressler, H.G. Hills, R.M. Adams \& N.H. Williams. 1969. Biologically active compounds in orchid fragrances. Science 164: 1243-1249.

Jenny, R. 1993. Stanhopea in Costa Rica \& Panama. Schlechteriana 4: 66-92. 
LANKESTERIANA 